\title{
Institutionalization and Organizational Long-term Success
}

\author{
Denise Fleck* \\ E-mail address: denise@coppead.ufrj.br \\ Instituto Coppead de Administração - Universidade Federal do Rio de Janeiro \\ Rio de Janeiro, RJ, Brazil
}

\begin{abstract}
Institutionalization processes have an ambivalent effect on organizational long-term success. Even though they foster organizational stability and permanence, they also bring about rigidity and resistance to change. As a result, successful organizations are likely to lose their competitive advantage over time. The paper addresses this issue through the investigation of the institutionalization processes of two long-lived companies: General Electric, a firm that has been a long-term success and its rival, Westinghouse, which was broken up after eleven decades of existence. The longitudinal, multilevel analysis of firms and industry has identified two different modes of organizational institutionalization. The reactive mode gives rise to rigidity and change resistance, much like institutional theory predicts; the proactive mode, on the other hand, neutralizes those negative effects of institutionalization processes. In the reactive mode, structure predominates. In the proactive mode, agency plays a major role in organizational institutionalization, and in managing the organization's relations with the environment, clearly contributing to environmental institutionalization.
\end{abstract}

Key words: institutional theory; organizational long-term success; modes of organizational institutionalization.

Received 21 February 2006; received in revised form 03 May 2006.

Copyright (C) 2007 Brazilian Administration Review. All rights reserved, including rights for translation. Parts of this work may be quoted without prior knowledge on the condition that the source is identified.

* Corresponding author: Denise Fleck

Rua Pau Marfim, 25, Rio de Janeiro, RJ, 22753-803, Brazil. 


\section{INTRODUCTION}

Implicit in the notion of long-term success are two other notions: competitive advantage (success), as suggested in the strategic management literature (Porter, 1980; Ghemawat, 1999), and persistence (long-term), as advanced in organizational studies (Meyer \& Zucker, 1989). Institutional theory (DiMaggio \& Powell, 1983; Meyer \& Zucker, 1989; Scott, 1987; Selznick, 1957; Stinchcombe, 1965) investigates persistence of behaviors and organizations, and suggests that though essential to fostering stability and permanence, institutionalization processes do not produce long-term efficiency, because they end up producing rigidity and resistance to change. Figure 1 portrays the ambivalent effect of institutionalization processes on organizational long-term success.

Figure 1: The Effect of Institutionalization Processes on Long-term Success

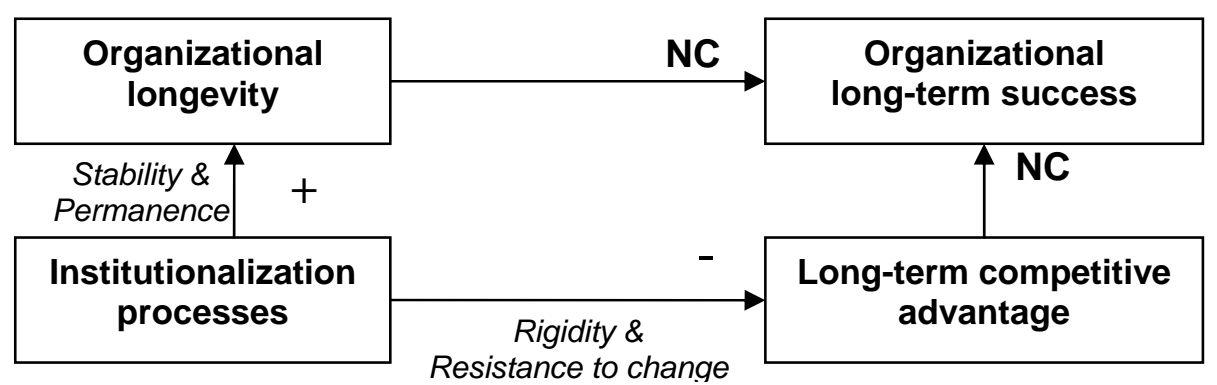

NC: Necessary Condition

Figure 1 prompts some possible conjecture concerning the long-term success of organizations: (i) it would be impossible; (ii) it might occur in the absence of institutionalization. To investigate this puzzling issue, this study scrutinizes the institutionalization processes of the American electrical industry and of two long-lived, influential electrical companies: General Electric (GE), a firm that has been successful over the long run and its rival, Westinghouse (WH), a firm that for several decades shared industry leadership with GE, but which was broken up after eleven decades of existence. Historical analysis has identified two modes of organizational institutionalization. While one allows the firm to renew its routines and relationships with the environment, and escape the side effects of institutionalization, such as rigidity and change resistance; the other leads the firm to develop a propensity to be affected by such side effects, to become a permanently failing organization (Meyer \& Zucker, 1989), and to face disintegration. The findings provide empirical evidence for pluralistic perspectives of institutional theory, such as Machado-da-Silva, Fonseca e Crubellate’s (2005) work.

The text is organized into three sections and a conclusion. It first presents an overview of select ideas in institutionalization theory. Next, the research method is described. Then, the historical case study is analyzed. Finally, the conclusion discusses the findings of the research.

\section{THEORETICAL BACKGROUND}

Institutional theory is multifaceted (Scott, 1987). Every institutional perspective addresses institutions and institutionalization processes, although different varieties emphasize different aspects of social systems. A striking indication of such plurality is the widespread notion of two main streams of research - the old and the new institutionalism. Both streams claim that institutionalization produces stability and persistence of structural forms and behaviors. Old institutionalism (OI) stresses processes, such as value infusion by leaders (Selznick, 1957), the work of people "who constrain 
people and organizations to conform to institution's exteriority” (Stinchcombe, 1965, p. 6), and imprinting - a process whereby new organizational forms acquire characteristics at the time of their founding that they retain into the future (Stinchcombe, 1965). Though much discussed, some ideas like imprinting have hardly been studied empirically (Scott, 1987). New institutionalism (NI), on the other hand, takes a more holistic approach, refraining from in-depth investigations of human agency throughout the institutionalization process.

Stinchcombe, an influential representative of the old stream, has censured new institutionalism for evacuating management from organizational studies (1997). Referring to the concept of institution to which he was first introduced, he states that "unlike institutions of modern institutionalism, people ran these institutions by organizing activities on their behalf” (p. 2). According to Stinchcombe, the removal of managerial agency weakens institutional theory: "the trouble with the new institutionalism is that it does not have the guts of institutions in it. The guts of institutions is that somebody somewhere really cares to hold an organization to the standards and is often paid to do that” (p. 17).

Showing concern for developing theory that is useful for managerial practice, Donaldson (2002) maintains that theories such as NI contradict the very essence of management, i.e. its ability to make as rational decisions as possible, because those theories claim that "organization is not about rationality, but about ritual and conformity to some ideology” (Donaldson, 2002, p. 101), producing institutional isomorphism (DiMaggio \& Powell, 1983). As a result, managerial adherence to conformity trades decision making uncertainty and voluntarism for environmental determinism.

Zucker's synthesis of institutional theories of organization (1987) identifies two distinct theoretical approaches. One, related to OI, views the organization as institution; the other, associated with NI, focuses on the environment as institution (see Table 1). Both the old and new streams put forward a counter-intuitive notion: that institutionalization processes increase chances of survival while reducing efficiency. Organizational institutionalization brings about organizational rigidity and resistance to change. Institutionalized fields produce isomorphism and organizational compliance to institutionalized rules and practices. Though essential for fostering stability and permanence, institutionalization processes do not result in long-term efficiency. Because well-established, yet obsolete, practices within organizations or throughout fields are not easily replaceable, in the long-run, organizations and fields will tend to operate at sub-optimal levels. A puzzling question, then, is to what extent, in a competitive, changing environment, are less efficient organizations likely to experience long-term success?

While acknowledging that institutions provide stability and order, Scott (2001) has maintained that they also undergo change. According to him, their study must address not only institutions as state of an existing social order, but also institutions as process, including the processes of institutionalization and deinstitutionalization. Applying process-oriented lenses to discuss institutional theory, Machadoda-Silva et al. (2005) have called into question the widespread dichotomist view that distinguishes the old and new streams in institutional theory. According to them, institutionalization should be regarded as a recurrent process (institutionalizing) where agency (emphasized in OI), structure (stressed in NI) and interpretation make up the building blocks of the process. In their view, agency and structure interact with and influence each other, and the reinterpretation of existing structures would allow their not necessarily verbatim reproduction. From a process-oriented perspective, therefore, the investigation of organizational long-term success in institutionalized fields requires scrutinizing the processes of formation (institutionalization), transformation and dismantlement (deinstitutionalization) of organizations (OI) and fields (NI), paying special attention to the interplay between agency and structure. This section briefly reviews select notions concerning institutionalization - of organizations and environment - and deinstitutionalization (Table 1 summarizes the main ideas). It first presents notions related to the institutionalization processes of organizations. Next, it advances select notions of environmental institutionalization. It then goes on to address deinstitutionalization processes, and finally offers a longitudinal perspective of institutional theory. 
Table 1: Institutional Processes of Organizations

\begin{tabular}{|c|c|c|}
\hline & ORGANIZATION & ENVIRONMENT \\
\hline $\begin{array}{l}\text { Institutionalization } \\
\text { Process }\end{array}$ & $\begin{array}{ll}\text { - } & \text { Value infusion } \\
\text { - } & \text { Elaboration of socially integrating } \\
\text { myths } \\
\text { - Elite formation, nurture and } \\
\text { renewal }\end{array}$ & $\begin{array}{ll}\text { - } & \text { Coercion } \\
\text { - } & \text { Mimetism } \\
\text { - } & \text { Normatism }\end{array}$ \\
\hline $\begin{array}{l}\text { Institutionalization } \\
\text { Outcomes }\end{array}$ & $\begin{array}{ll}\text { - } & \text { Non expendability } \\
\text { - } & \text { Character formation: Distinctive } \\
& \text { competence / Distinctive } \\
& \text { inadequacy } \\
\text { - } & \text { Stability \& inflexibility } \\
\text { - } & \text { Sub-optimal performance }\end{array}$ & $\begin{array}{ll}\text { - } & \text { Isomorphism } \\
\text { - } & \text { Inertia } \\
\text { - } & \text { Sub-optimal performance }\end{array}$ \\
\hline $\begin{array}{l}\text { Threats to institutional } \\
\text { formation and } \\
\text { maintenance }\end{array}$ & $\begin{array}{ll}\text { - } & \text { Opportunism } \\
\text { - } & \text { Utopianism } \\
\text { - } & \text { Benign institutional environment }\end{array}$ & - $\quad$ Fast changing technology \\
\hline Deinstitutionalization & $\begin{array}{l}\text { Political pressures } \\
\text { - } \quad \text { Mounting performance crisis } \\
\text { - } \quad \text { Conflicting internal interests } \\
\text { Functional pressures } \\
\text { - } \quad \text { Changing economic utility of a } \\
\text { practice } \\
\text { - } \quad \text { Increasing technical specificity } \\
\text { Social pressures } \\
\text { - } \quad \text { Increasing social fragmentation } \\
\text { - } \quad \text { Decreasing historical continuity }\end{array}$ & $\begin{array}{l}\text { Political pressures } \\
\text { - } \quad \text { Increasing innovation pressures } \\
\text { - } \quad \text { Changing external dependencies } \\
\text { Functional pressures } \\
\text { - } \quad \text { Increasing competition for } \\
\text { resources } \\
\text { - } \quad \text { Emerging events and data } \\
\text { Social pressures } \\
\text { - Changing institutional rules and } \\
\text { - } \quad \text { alues } \\
\text { discreasing structural }\end{array}$ \\
\hline
\end{tabular}

\section{Organizational Institutionalization}

Selznick, one of the founding fathers of institutionalism, distinguishes organizations from institutions (Selznick, 1957). The former are expendable, can be sold, outsourced or simply extinguished; the latter are valuable and indispensable, must not be discarded, but ought rather to be preserved. For Selznick, institutionalization is the process whereby an organization becomes an institution. It happens over time as the organization is infused with value "beyond the technical requirements of the task at hand" (p. 17). One of the most important techniques for infusing long-run meaning and purpose to day-to-day behavior, according to Selznick, is "the elaboration of socially integrating myths” (p. 151). 
The transformation of organizations into institutions is "marked by a concern for self-maintenance" (Selznick, 1957, p. 20). This means two things. First, self-maintenance implies a need for "a certain permanence and stability" (p. 21). Second, as the organization gains stability, it loses flexibility, because stability gives rise to habits, making it difficult to implement administrative changes. The search for self-maintenance brings about "a need to accommodate internal interests and adapt to outside forces in order to maintain the organization as a 'going concern', minimize risks, and achieve long-run as well as short-run objectives” (p. 21). In Selznick's view, organizational rivalry is perhaps the most important problem in organizational life.

According to Selznick, institutionalization can be viewed as a process of organizational character formation. Being a historical product, organizational character comprises "repetitive modes of responding to internal and external pressures" (p. 16). As organizations become institutions, they are infused with value, producing a "distinct identity for the organization" (p. 40). Selznick's notions of organizational values and character do not necessarily imply organizational virtue and effectiveness. As he states: "in studying character we are interested in the distinctive competence or inadequacy that an organization has acquired” (p. 42).

Leardership plays a vital role in institutionalization. The key tasks of leaders include: the definition of institutional mission and role; the institutional embodiment of purpose; the defense of institutional integrity; and the ordering of internal conflict. It is up to leadership not only to create but to preserve values.

Selznick defines institutional integrity as "the persistence of an organization's distinctive values, competence, and role” (p. 119). "Institutional integrity is characteristically vulnerable", he maintains, "when values are tenuous or insecure" (p. 120). To protect institutional integrity, leadership should avoid opportunism and utopianism. Opportunism is defined as "the pursuit of immediate, short-run advantages in a way inadequately controlled by considerations of principle and ultimate consequence" (p. 143). The greatest danger of opportunistic moves lies in the uncontrolled effects such moves may bring to organizational character. Utopianism escapes the functions of leadership avoiding "hard choices by a flight to abstraction" (p. 147). One source of utopianism is the overgeneralization of purpose to guide decision; another one consists in hoping that "the solution of a technical problem will solve institutional problems" (p. 148).

To Selznick institutional leadership is about striking a balance between stability and change so as to develop learning capabilities. "The leader's job", maintains Selznick, "is to test the environment to find out which demands can become truly effective threats, to change the environment by finding allies and other sources of external support, and to gird his organization by creating the means and the will to withstand attacks” (p. 145). Leadership must not only foster cohesion towards institutional security, but create conditions "that will make possible in the future what is excluded in the present" (p. 154).

\section{Environmental Institutionalization}

The study of institutionalized practices at the environment level contributes to the notion of organizational field, connoting "those organizations that, in the aggregate, constitute a recognized area of institutional life: key suppliers, resource and product consumers, regulatory agencies, and other organizations that produce similar services or products” (DiMaggio \& Powell, 1983, p. 148). According to Meyer and Rowan (1977), both technology and regulation are sources of organizational practices in a field. New organizational practices come into being by virtue of technical or economic requirements of the task. Once such practices gain legitimacy, others in the field imitate the practices and uncritically accept their validity and value.

As practices spread throughout a field, this one becomes isomorphic (DiMaggio \& Powell, 1983), practices are hard to change, and efficiency is reduced. Conformity to field practices results from taken-for-granted social norms, which define 'the way things are' and/or the 'way things are to be 
done' (Scott, 1987). Three explanatory processes of isomorphism are suggested (DiMaggio \& Powell, 1983): imitative (mimetic) adoption of others' successful elements; normative transmission of social facts from external sources such as professions; and coercive enforcement of practices.

Change in existing practices usually requires the action of forces external to the field. Two change mechanisms in institutional environments have been advanced (Leblebici, Salancik, Copay, \& King, 1991). Both refer to the action of powerful organizations: either those organizations force their immediate relational networks to adapt to their practices, or they attempt to insert their goals and practices into society as institutional rules. In the event of major fast changing technological processes, the institutionalization of practices is precluded, until the rate of change reduces, allowing institutionalization to emerge.

In conjunction with technical functions, institutionalized organizations serve mythical functions (Meyer \& Rowan, 1977). As a result, institutionalized organizations perform important legitimating functions which cause core tasks to be more poorly performed than would be the case in a marketoriented organization.

\section{Deinstitutionalization Processes}

According to Oliver (1992, p. 564), deinstitutionalization "refers to the delegitimation of an established organizational practice or procedure as a result of organizational challenges to or the failure of organizations to reproduce previously legitimated or taken-for-granted organizational actions". Within a longitudinal perspective of organizations, the study of deinstitutionalization complements the analysis of institutionalizing processes.

Oliver's arguments in favor of such a study rest on three elements: the potential for explaining a broad range of changes in organizations; the possibility of revealing the conditions under which institutionalized pressures are least likely to exert an enduring influence on organizations; the opportunity to examine the failure of institutional pressures for conformity. Distinguishing the organizational and the environmental levels of analysis, Oliver suggests a number of political, social and functional mechanisms of deinstitutionalization (see Table 1).

\section{A Longitudinal Perspective of Institutional Theory}

From a longitudinal viewpoint of the formation and development of organizations and organizational fields, the OI and NI streams constitute complementary perspectives. Each stream contributes understanding of different phases in the existence of organizations and fields. OI emphasizes the agency of the organization by means of its leadership throughout the organizational character formation phase. NI stresses the inter-organizational field structure, which is deep-rooted in the stable phase of organizational and field existences. As Machado-da-Silva et al. (2005) have suggested, agency and structure interact when the institutionalization phenomenon is examined longitudinally. From a dynamic perspective, it is conceivable to suppose that the agency-structure interaction is likely to be more intense when both organizations and field are in the formation phase, or also, when the emergence of new organizations brings about change in the existing field's structure. In such circumstances, not only may the visible hand (Chandler, 1977) of management (OI) contribute to environmental fashioning, but the environment may also contribute to the fashioning of the organization's traits of character. Being typically longitudinal, multilevel historical studies are especially adequate for investigating the dynamic aspects of the agency-structure interaction in institutionalization and deinstitutionalization processes. 


\section{RESEARCH METHOD}

Various kinds of secondary data pertaining to the American electrical industry and its top two companies were used: historical studies describing specific themes, people and periods of time, in addition to periodicals that provided information on a regular basis throughout the investigated period (the 1870s to the late 1990s). Two business bibliography books (Daniells, 1957; Geahigan, 1988), dissertation abstracts and book reviews helped to identify historical studies on the subject. The sources that provided regular information were: Moody’s Industrial Manual (from 1923 to 1997) - each annual edition includes a brief company history, its businesses, acquisitions and divestitures, debt and capital profile, and financial data; Fortune Magazine (1930 to 1999) and Business Week (1930 to 1947) both magazines were perused in search of articles, reported news and advertisements; annual reports of General Electric and Westinghouse (1971 to 1999). In total, 57 books, 13 case studies, 21 academic papers, and over 250 press articles constituted the premier sources of information for this study.

The reading of the material sought to identify relevant historical facts. These were organized in a number of ways:

(i) Industry level - Inside and around events listed with chronological arrangement of events taking place inside the American electrical manufacturing industry, as well as around the industry;

(ii) Sector level - Events listed per industrial sector, within the electrical industry;

(iii)(III) Firm level - GE x WH general comparative list, summarizing financial, operational, organizational and inter-organizational information on each company.

The longitudinal multilevel study of twelve decades in the history of the electrical industry sought to reconstitute the developmental path of firms and industry in the electrical field. Selznick (1957) provided the rationale for establishing evidence of institutionalization in each company. According to him, institutionalization is a process of character formation, and the organizational character is made up of repetitive modes of responding to external and internal pressures. The chronological order (Hill, 1993) of the selected events and processes enabled us to establish organizational and environmental change paths. Change paths underwent three main analyses: within-case and cross-case (Eisenhardt, 1989), and aggregated. Through within-case analysis, evidence of similar organizational behavior at different points in time and under different management teams suggested institutionalization of such behavior in the analyzed organization. By means of cross-case analysis, parallel comparisons (Hill, 1993) between the chronologies of GE and WH enabled us to compare institutionalization processes of two companies that in several respects faced quite the same environment. Analysis of the differences between GE and WH sought to identify the presence or absence of agency. Similar behavior, on the other hand, suggested the likelihood of isomorphism in the industry. Finally, aggregated analysis of the behavior of various actors in the field indicated industry institutionalization whenever analysis found evidence of sustained similar behavior (or sustained norms) over long periods of time. The findings of the inductive study have identified two different modes of organizational institutionalization. One requires considerable managerial capabilities when it comes to dealing with the environment and responding to external and internal pressures. The other is characterized by leadership subordination, to external and internal pressures.

\section{INSTITUTIONALIZATION IN THE ELECTRICAL INDUSTRY}

'Famous name Westinghouse fades away' announced a newspaper (Aeppel, 1997). The opening sentence following the headline was thought-provoking: 'How does the century-old name of an 
American industrial giant such as Westinghouse Electric Corp. vanish so quickly?' The decision had been taken for the 110-year-old Westinghouse Corporation to be broken up in order to focus on its broadcasting businesses, while its longtime rival, General Electric continued to thrive.

From their inception, General Electric (GE) and Westinghouse (WH) were high-tech companies in an industry that diversified into numerous related industrial sectors. Westinghouse Electric Company, a new venture launched by George Westinghouse in 1886, was formed to develop the alternatingcurrent (ac) system of electrical distribution when the direct-current (dc) system was dominant. General Electric Company was formed in 1892 by means of a combination of two pioneer, high-tech firms in the electrical industry: Edison General Electric and Thomson-Houston.

They electrified cities, provided them with illumination, made thousands of consumer products and pioneered in electronics and telecommunications. They diversified both functionally and technologically. Besides inventing and manufacturing, they branched out into marketing, distribution and finance. To develop increasingly complex products and systems, they extended their knowledge into the electrical, mechanical, chemical and nuclear fields. In so doing, both companies experienced continuous growth, reaching gigantic proportions.

The industry developed into a duopoly with hundreds of small companies orbiting GE and WH. For several decades the two companies competed in the same businesses and markets, ferociously fighting a technological battle in many fronts of scientific knowledge. Nevertheless, they shared a number of common commercial practices, having at times joined forces in a combined effort to promote classes of products, at other times to pursue new entrants, and at still other times to face changes in legislation. Small companies sought to align their businesses with the two giants in an environment of controlled price and production quotas. This conferred quite a great deal of stability on the industry as a whole.

Over time, however, industry stability and duopolistic dominance faded away. The carefully crafted set of industry relations was challenged. A number of Court decisions ruled out established industry procedures and agreements, resulting in the dismantlement of the industry structure. Under the new rules, tough commercial competition entered the business landscape. While the two big companies continued to diversify their activities, high-tech start-ups entered new promising technology fields, bringing in new, flexible, fast-moving contenders. From then on, GE and WH started to diverge from one another to such an extent that by the mid 1970s their business portfolios were only narrowly similar. Even in common businesses, they employed different procedures, such as in the case of nuclear plants, which caused WH such a huge loss that it faced bankruptcy.

Why did these two industry leaders, which shared a common history of industry formation, development and achievements, end up having such different destinies? What could possibly explain how, while WH was being buried, GE was being acclaimed as the best managed company in the world? Was it a matter of bad luck, unfortunate mistakes and wrong diversification choices?

\section{General Electric's and Westinghouse's Character Formation}

The analysis has identified repetitive modes of response to external and internal pressures, i.e. organizational character (Selznick, 1957) traits, at GE and WH. From GE's inception, its management faced huge challenges: the integration of two long-time rivals - Edison General Electric (EGE) and Thomson-Houston (T-H) - and a threat of bankruptcy. To overcome this life-and-death struggle, GE took containment measures (conservative accounting) and sought productive efficiency (scale and scope economies), promoting, whenever possible, the integration of company units. Throughout the examined period, GE's management consistently voiced concern over the risk of bankruptcy, so much so that GE would develop a high awareness of risk. GE would not only continue and refine Coffin's (GE's first President) conservative policy over time, but would also institutionalize the auditing function. Moreover, systematic evaluation of opportunities would help to prevent GE from endangering the whole organization. For example, in 1946 GE succeeded in seeding a cloud and producing an artificially precipitated snow-storm (Hawkins, 1950). The seeding operation indicated 
some practical, commercial possibilities, but GE scientists believed that the chances of controlling large weather patterns such as droughts were too low. As a result, the project was discontinued, because "company officials were worried about possible damage suits arising out of the work" (Birr, 1957, p. 169).

Believing that managerial succession may also put the very existence of the organization at risk, GE paid increasing attention to succession processes, which over time came to encompass succession at several levels of the organizational structure. GE has also consistently devoted attention to promoting the integration of organizational parts. These include a corporate advertisement policy in the 1920s, an organizational program to foster the GE family and attach the GE monogram to every product in the 1930s, and the carefully-planned and tested coordinated decentralization of the 1950s.

$\mathrm{WH}$, on the other hand, developed a propensity to face unnecessary, avoidable solvency risks, to operate below the efficiency boundary, and to foster organizational fragmentation. At WH, systematic risk assessment was absent. As a result, new ventures were left unattended, giving rise, sometimes, to huge losses that could have been avoided. Examples of this behavior include WH's expansion in the 1970s, uranium contracts for nuclear plants, and risk management at WH's financial subsidiary, which had to be closed down. In addition, on more than one occasion, the company faced succession discontinuities, and was once managed by an interim CEO for as long as two years. Fragmentation was another trait of WH's character. WH was created as a member of George Westinghouse's fragmented empire. George Westinghouse's approach to firm growth consisted of adding quasiautonomous manufacturing units both domestically and internationally, while reserving to GW himself the role of integrator. Under his command, WH grew in the same fragmented way, both domestically and internationally. Over time, fragmentation was consistently reinforced. As GW was ousted, the arrival of his replacement, Guy Tripp, an outsider financier, introduced another kind of fragmentation: not only were manufacturing units kept apart from each other, but top management became considerably more dissociated from WH's operations. In fact, upon Tripp's arrival, although WH's finances were put back into shape, fragmentation was reinforced. Also a foreigner, his successor, A. Robertson, kept manufacturing disconnected from the sales organization, having introduced fragmentation at the functional level. Over time, poor integration attempts were easily neutralized, reinforcing the company's familiar fragmented structure.

The cultivation of myths has been a recurrent feature at GE. GE has promoted symbols as a way to reinforce its identity both inside and around the company. Coffin, for example, maintained the cult of Thomas Edison, popularizing the Research Laboratory as The House of Magic, and pushed his successors - Owen Young and Gerard Swope - into the public eye. While Coffin himself refrained from becoming a symbol, the reputations of engineers and inventors such as Willis Whitney, Irving Langmuir and Charles Steinmetz were largely promoted. Over the years, most of GE's CEOs and several of GE's managerial procedures set new standards of behavior and best practices for business in general. Quite often has GE been described as the 'best managed company in the world'. By nurturing such a high organizational image, the threat of fragmentation by virtue of organizational rivalry has been neutralized.

$\mathrm{WH}$, in turn, failed to cultivate integrating myths. So much so that WH's founding father, George Westinghouse, a prolific inventor that successfully challenged the electrical industry in his defense of the alternate current, not only did not turn into an enduring organizational myth, but ended up being banished from the company he had organized. Had WH ever had an enduring myth, this would likely have been the company's high-tech innovation capabilities. As a matter of fact, WH's major weapon, technological innovation, became its way of life, and a clear trait of character. From the beginning, WH defied the electrical industry worldwide when George Westinghouse proposed the ac system. WH's research personnel took pride in their accomplishments, even if, from a practical viewpoint, they sometimes missed the point. An episode in the 1930s illustrates this organizational trait. WH's president called a meeting at a room that had recently had installed a new acoustic system. So soundproof was the system that nobody could hear what the president was saying. After a while, WH's engineers in the audience were both amused and proud at their accomplishment, even though they knew the system would need to be adjusted, if they wanted to sell it for meeting purposes. Throughout 
WH's existence, research personnel developed a number of futuristic projects that never made it onto the market - as if in a perennial search for the replication of George Westinghouse's outstanding ac triumph. In the 1980s, Jack Welch still feared WH's outstanding technological competence when he mentioned to an MBA audience GE's need to watch out for WH instead of getting its management involved in elaborate strategic planning exercises.

As often as possible, GE has replicated its expertise in solving technological problems to solve administrative and business issues. This requires that those issues be treated as objectively as possible, so as to compensate for unavoidable organizational politics. Measurement through indicators has been persistently stimulated to the point of having Jack Welch mention the company's efforts to measure the 'soft' qualities of its personnel. GE's ability to contribute to the fashioning of the environment began early on. Starting with the cross-licensing agreement with WH in 1896, GE conceived a number of schemes to foster stability in the relations with suppliers, clients and rivals. By keeping output volume and price under control, it not only prevented industry players from running into a price war, but also secured handsome profits for everyone - though considerably lower than GE's. Upon expiration of its license contracts in the late 1920s, GE's new licenses covered improvement and process patents. In the 1950s the courts put an end to a number of schemes, but GE continued to shape its relations with the environment. During the 1950s and 1960s GE conducted negotiations with labor unions through Boulwarism - a collective bargaining concept GE had conceived that minimized the role and the power unions might have in the process. In the 1970s, GE conducted systematic studies into inflation, having launched a management-education program, COIN, i.e. Effectively Coping with INflation. In two years, around 3,000 GE managers had been trained, as well as representatives of about 50 other large companies. GE shared its insights with corporate visitors, believing that to the extent that all of American industry knew its real costs, pricing would be more realistic, and all firms would benefit.

Unlike GE, WH did not apply its superb problem-solving skills in technology to administrative and business issues. As a result, WH would commit the whole organization, as during its diversification years, based on partial assessment of the situations (Selznick, 1957). WH lacked a well-forged policy to handle labor unions. It would occasionally follow the lead of General Motors and negotiate a similar deal with unions. At the bargaining table, WH would be soft sometimes; hard other times, and once in a while it would face several months-long strikes. When it came to fashioning the environment, $\mathrm{WH}$ played a secondary role which comprehended fighting for a privileged position in the industry, rather than dictating rules and practices to other players. When the cross-licensing agreement was signed with GE in 1896, WH's share of the market for the next 15 years was determined proportionally to the patents value each company held then - every time WH grew 3 times, GE would grow 5 times. As the second best player in the industry, WH bargained with GE for privileged conditions in their agreements, and together the two dominated the industry. Although the second-best learned to deal with the number 1 company, WH relied on GE to coordinate the stabilizing actions in the industry. As a result, WH failed to become skillful in handling the environment, and would tend to follow, rather than set, industry trends. After WWII, the competitive landscape greatly changed, and following the trend of the 1960s and 1970s, WH became a diversified conglomerate of unrelated businesses.

Historical analysis, therefore, has identified some traits of character of each company. As mentioned before, those traits differed in several respects. The study has also amassed evidence concerning the active role of GE's leadership (Selznick, 1957) in the company's institutionalization, as well as in the environmental institutionalization. The visible hand of GE's management (Chandler, 1977) was proactive and assertive with regard to setting goals, building organizational traits of character, and affecting intra-industry relations. WH's leadership was significantly less active and much more reactive, submissive, and at times hesitant, concerning WH's responses to internal and external pressures. Moreover, GE's trait regarding systematic problem solving has allowed GE to escape opportunism and utopianism (Selznick, 1957), while WH fell prey of both traps.

Finally, the multilevel historical analysis enabled reconstituting the formation process of relationships among industry players. GE's systemic worldview, according to which industry stability 
was essential for GE's own success, provided guidelines for several strategic moves the company made, and played a major role in industry institutionalization, as described below.

\section{Institutionalization Processes in the Industry}

The development of two electrical sectors - electric lamp and apparatus - is representative of industry institutionalization. In both cases GE's initiatives actively helped environmental shaping. GE used the monopolistic power of its patents to dictate rules and practices to the other players. Coercive, mimetic and normative mechanisms produced industry isomorphism up to the late 1950s, when the Justice department challenged industry practices.

Up to the late 1950s, the two integrated electrical companies evolved their portfolios of businesses in very similar ways, competing in virtually every line of business except radio broadcasting, elevators and escalators (where GE did not compete).

The structure of the American electrical manufacturing industry evolved into an umbrella structure. By coordinating industry players, actively promoting innovation, and neutralizing external sources of change, GE systematically crafted a protective cover for electrical manufacturing firms. As the industry coordinator, GE occupied center stage, and reserved a privileged position for $\mathrm{WH}$, while most other industry players orbited these two companies. During this period, the most important business segments were the electric lamp, apparatus, and appliances. While lamp profits were proportionally the highest and the most regular in the industry, apparatus accounted for the bulk of sales, which heavily depended on the state of the economy. Appliances were the most promising segment. Most importantly, the umbrella structure provided all players with handsome returns.

Umbrella shaping started at a very early stage. To reap the potential benefits of Edison's lamp patents GE initiated a number of coordinating actions in the industry: supplier agreements in 1895 (glass bulb, lamp-making machinery), patents cross-licensing agreements with WH (1896), market sharing agreements (1896), the organization of the incandescent lamp manufacturing association (ILMA) in 1896, and financing rivals (1901). ILMA set prices based on GE's prices and fixed production volume keyed to GE's sales. GE's financing of independent lamp manufacturers was done through a holding company (National), $75 \%$ owned by GE. The GE lamp business strategy aimed at two major goals: to maximize margins and to avoid price-based competition.

In 1924, the government filed an antitrust suit against GE and WH. These companies faced the charge that the license agreement between them and their agency system of lamp distribution were illegal. In November 1926, the Supreme Court stated that GE owned patent rights that covered entirely the manufacturing of electric lights with tungsten filaments, and that secured to GE the monopoly of their making, using and vending. This decision in fact held that a license to produce a patented product may include a price-fixing clause. In June 1928, GE and WH agreed to sign a new “A-type” agreement dated as of January 1, 1927, and scheduled to run until 1944.

Margin maximization calls for an increase in value perception and a reduction in manufacturing costs. Product (GEM, tungsten, Mazda lamps) and process (lamp manufacturing) innovation developed at GE's research laboratory enabled GE to achieve both goals. To neutralize potential sources of downward price pressure, that might set in motion a price war, GE sought to keep under control both production volume and product price in the industry. Its licensees were given production quotas relative to GE's own production. As a result, the whole industry would harmoniously increase or eventually reduce production, avoiding the formation of undesirable inventory, and also avoiding strong pressures on product price. In addition, through its commercial practices, which evolved from retail price fixing to consignment schemes, GE would set industry prices.

GE's strategy in the lamp business was extremely successful. Lamp profit margins were the highest among electrical products, not only contributing significantly to GE's total profits, but also protecting the firm from losses during the depression years (in 1933, for example, the $\$ 17.6$ million income in lamp neutralized the $\$ 11$ million losses in all other GE businesses). GE’s initiatives did bring stability 
and profits for all industry players. However, profits were unequally distributed among participants GE kept the largest share of profits in the industry. WH, in turn, occupied a privileged, second-best position in the lamp manufacturing industry.

The structure of the electrical apparatus industry also took an umbrella form. Cross-licensing between GE and WH and the complex nature of the custom manufactured products contributed to limit the number of integrated manufacturers in the industry. As a matter of fact, GE and WH dominated the apparatus segment, holding the two largest shares of the market, while facing a number of smaller, specialized rivals, such as Allis Chalmers. GE's relationship with foreign electrical manufacturing companies protected the American market from foreign competitors.

Price control was stimulated on several occasions. In 1926 industry firms organized around NEMA (the National Electrical Manufacturers' Association), which resulted from the merger of three industry associations. NEMA intended to cooperate with the American Department of Commerce in standardization and simplification. Its meetings fostered cooperation among competitors to establish, among other things, a uniform accounting system. Industry players expected such efforts to result in uniform prices. Each electrical manufacturer sent delegates to NEMA meetings to exchange market statistics and other information in addition to seeking to further the adoption of standardized product quality, dimensions and ratings. These meetings fostered cooperation among competitors in several fronts. Intent on avoiding any appearance of illegal collusion, NEMA members steered clear of price discussions. However, discussions of standard cost-accounting systems and of average cost were held. According to one company attorney, clear efforts were made "to establish a uniform system of accounting, which naturally results in uniform prices.” (Sultan, 1974, p. 29) Aware of the increasing antitrust enforcement, most companies were prudent when it came to holding meetings with competitors. As a result, the practice of holding two types of meeting - an official one with minutes duly recorded and NEMA officials present, and an informal one with off-the-record discussions emerged.

During the Great Depression, the National Industrial Recovery Act (NIRA) discouraged price competition in the light of the huge drop in electrical equipment orders during the 1930s, when sales plummeted from \$81 million to \$16 million between 1929 and 1933. To help implement the Act and restore business vitality, NIRA created the National Recovery Administration (NRA) agency. NRA promulgated codes of fair competition, whose violation was subject to government penalties. Selling below the list price became not only an unfair but also illegal trading practice. Any price change had to be announced by issuing new price sheets. As a result, NRA's scheme helped to prevent the erosion of prices and to foster market share stability. During the 1930s, the informal, "off-the-record" meetings between competitors tended to focus on price levels. Given the price-checking activities fostered by the governmental agency, the younger engineers and managers were often persuaded that such meetings with competitors were common. In 1935, however, the US Supreme Court judged the NRA scheme to be invalid. In consequence, the informal meetings went underground. The American government reestablished control over prices during WWII. After the war, informal underground meetings to fix prices, organize sealed-bids, and establish market shares contributed toward reduce price-based competition and fostering market share stability.

In addition, utilities companies were not qualified to integrate backward into apparatus manufacturing. Their dependence on apparatus manufacturers was extremely high. As a way to counterbalance the power of the manufacturers, especially the GE-WH duopoly, utilities would stimulate competition between manufacturers and, whenever possible, distribute an order among competing firms. Interestingly, it was in the best interest of most players - utilities, government (as customer and ruler) and the companies (GE and WH) - that both GE and WH were in good shape.

By helping to shape the umbrella strategy, GE simultaneously built defenses for the whole industry and underwent productive expansion. Under favorable external conditions, the whole industry would grow synchronically. In the event of unfavorable conditions, the whole industry would contract and GE would take advantage of the adverse condition to improve its productivity. 
In short, factual evidence suggests that the electrical industry experienced isomorphism and suboptimal performance. In both sectors - lamp and apparatus - in several respects, the behavior of industry players became homogeneous and subordinate to institutionalized rules and practices, many of which had been introduced by GE. The market mechanism failed to promote efficiency on account of GE's initiatives, as well as, on certain occasions, of government itself.

Through the longitudinal analysis of the evolution of practices, the study has identified the active role of firms and government, i.e., the visible hand of management took part in the institutionalization of the field. Once the field structure had been set in place, there followed inertia and change resistance among players. For example, despite increasing signs of legitimacy erosion concerning the practice of meeting rival firms, such meetings went underground and persisted until the courts punished firms and individuals in the early 1960s. Such events led to industry deinstitutionalization, as shown below.

\section{Deinstitutionalization Processes in the Industry}

In the 1930s, different types of pressure (Oliver, 1992) - antitrust suits, patents expiration, foreign competitors - started to menace the industry structure in place. An antitrust suit against RCA was initiated in 1930, which called into question the relations of GE and WH with RCA. A consent agreement was reached a few years later, whereby GE and WH would not anymore hold stock positions in RCA. In 1933, GE lamp patent ran out, but GE managed to grant new licenses to its licensees, in essentially the same form, scheduling licenses to run out in 1944.

In addition, several companies that licensed GE patents started to take independent initiatives, signalling their search for autonomy. In 1937, for example, WH created an overall advertising department, initiating high-powered institutional advertising for the first time in its existence. A huge effort at the time, WH's advertising appropriation was $\$ 4.3$ million, nearing its $\$ 5.5$ million R\&D budget. In 1938, Sylvania, a lamp producer, came out with its own fluorescent lamp shortly after GE \& WH had announced their fluorescent line. Moreover, in the mid-1940s GE's lamp licenses expired and were not renewed.

During the war, the granting of new patents was suspended so as not to impact the war effort. Cooperation among peacetime competitors was to take place in several instances, such as the handling of common supplies, and knowledge transfer. Law suits were suspended for the duration of the war. A case in point is the 1941 Government suit against GE, contending that the last basic patent on incandescent lamp had expired in 1933, thereby alleging that the licensing system constituted an illegal restraint of trade.

By the late 1950s, both companies had heavily diversified into appliance manufacturing to complement their apparatus and lamp businesses. The electrical industry, however, was under close scrutiny from the Justice Department. In fact, GE, WH and 27 other electrical manufacturers were facing the courts. The trial came to an end in 1961, revealing that GE had been involved in 19 conspiracies, concerning products, which accounted for more than 10\% of GE's total sales. Several firms, including the top two received fines and several managers were imprisoned.

\section{Discussing the History of Firms and Industry}

Factual evidence indicates that long-term success and institutionalization can coexist. In fact, after eleven decades of sustained success exhibiting highly identifiable traits of character, GE did not seem to face decline in its admittedly high performance standards. On the other hand, the study also indicates the coexistence of organizational failure and a distinctive character that features inadequacies, such as those WH cultivated - organization fragmentation and bankruptcy risk exposure. As a result, Figure 1's description of the relationship between institutionalization processes and organizational long-term success is only partially accurate. 
WH's consistent behavior throughout its existence suggests that one should discard explanations for failure such as bad luck, unfortunate mistakes and wrong diversification choices. After all, now and then any firm may face such adversities, so much so that GE did not succeed in the computer business, lost leadership and eventually exited the electronics segment, and was forced to forego a number of diversification attempts.

On the other hand, historical evidence suggests that the development of an organizational learning attitude is a key issue for long-term success. The development of two traits of character seems to play a main role: (i) systematic approach to issues and problems; and (ii) systemic perspective of the firm vis-à-vis its relevant environment. The systematic and systemic GE was proactive in its pursuit of clear goals: minimizing bankruptcy risk, maximizing efficiency, neutralizing internal conflicts, and fomenting environmental stability that might help maximize its chances of keeping market, technological and managerial leadership in the industry. The poorly systematic and systemic $\mathrm{WH}$ became a hesitant victim of its own conflicting goals, having to a large extent behaved in a reactive way, vis-à-vis the environmental dictates. This article proposes to name GE's institutionalization mode proactive, and WH's reactive.

Agency is clearly present in the proactive mode. GE made full use of the collection of response strategies (Oliver, 1991) to respond to both the environmental and its internal stakeholders' pressures. Whenever possible, GE sought to employ manipulation and defiance strategies (Oliver, 1991), while whenever needed, it made use of avoidance, compromise and acquiescence strategies (Oliver, 1991). The strong visible hand of its management was present during the building of organizational character and of the umbrella industry structure. On the other hand, agency is clearly weak or absent in the reactive mode. Even though WH did at first successfully employ the defiance strategy, over time WH's response power to environmental pressures was progressively neutralized by GE, and weakened: at times by its poor agency, at times by its managers' disregard for issues involving internal conflicts. It could be said that WH's behavior typifies the NI stream.

Also clear in the historical study is the impact of structure over the organization and its traits of character. For example, the industry practice of meeting rivals was to such an extent institutionalized within both GE and the industry as a whole, that it took GE's top management to openly and strongly fight it in the 1950s. On three different occasions, to no avail, GE requested its employees' written acknowledgement of the firm's policies regarding meetings and talks with rival firms, but most of GE's salesmen failed to discontinue the several-decade-long practice of meeting rivals. Only after the punishment of firms and managers in the 1960s trials was the practice discontinued within GE.

\section{CONCLUSION}

In his overview of forty years of organization studies, Selznick (1996) criticizes the segregation of the old and new institutionalism. Selznick maintains that an important downside of this separation is the "failure to integrate the old and new by taking account of theoretical and empirical continuities" (p. 275). As a result, Selznick calls for a reconciliation of the old and new schools, pointing out the need to direct attention "to genuine problems of institutional life, which may not be the same as the problems that intrigue institutional theorists” (p. 277). In a similar vein, Scott (1987, p. 509) suggests that "institutional arguments need not be formulated in opposition to rational or efficiency arguments but are better seen as complementing and contextualizing them".

The historical study in this paper addresses the calls for reconciling new and old institutionalism and to integrate efficiency and institutional arguments. For one, the comprehensive analysis examined both organizational and environmental institutionalization processes. In addition, the paper proposes the notions of active and reactive management to institutionalization processes, maintaining that active management neutralizes institutionalization outcomes, which reduce organizational efficiency. The active mode views institutionalization as an instrument for organizational healthy perpetuation. The 
reactive mode, on the other hand, regards institutionalization as an organizational fact of life that imposes itself on the organization.

The evidence amassed suggests that GE performed an active management of institutionalization. At GE, leadership played an active role in the formation and nurturing of values and myths, in shaping organizational traits that foster and protect organizational integrity and renewal, and in scrutinizing the environment. Whenever possible, GE would seek to introduce practices and rules, and force them upon the environment. If not possible, GE would seek to anticipate environmental change so as to be prepared for it.

WH's institutionalization, on the other hand, was weaker and passively managed. Its distinct competence concentrated on a specific function - research and development. Strong values supported R\&D work, but they were insufficient to foster the unity of WH's several parts, so much so, that after WH's acquisition of Infinity Broadcasting in the 1990s, Infinity's chairman became WH's largest shareholder, seeing no value in keeping the old industrial operations. WH's leadership neglected its role in shaping institutionalization processes both inside and around the company they managed. Leadership omission left internal conflicts unattended, institutionalized procedures unchecked, and the organization exposed to environmental changes.

The historical analysis has shown the strong effects that environmental events such as financial crises, economic depressions, inflationary regimes, legislation, and wars have had on the firms and the industry. It has also shown that the visible hand of management (Chandler, 1977) can play a vital role in protecting the organization from external threats. In many respects GE and WH faced very similar environmental pressures. However, GE's management continually defended GE's integrity, while WH's allowed the company to drift.

Organizational institutionalization is, therefore, neither good nor bad in itself. It may, however, create good as well as bad habits. Good habits such as the systematic problem solving of administrative issues and superior ability to handle environmental pressures are likely to foster a proactive institutionalization process, which neutralizes rigidity and change resistance. On the other hand, bad habits like unsystematic problem solving, and the inability to handle external pressures are likely to give rise to a reactive institutionalization process, which promotes rigidity and change resistance, and reduces long-term success chances.

The analysis has clearly shown the visible hand of management in fashioning environmental institutionalization. In the case of the electrical industry, managerial action over the environment did indeed forge a particular industry structure. Stable and profitable, the industry grew and contracted in concert. In other words, the industry also underwent a process of institutionalization, where smaller players were forced to mimic others, giving rise to isomorphism. In this particular industry, for a number of years, favorable competitive conditions secured handsome outcomes for most of the players. This rather benign institutional environment produced lethargy and the false notion of organizational success. In addition, historical analysis has also found evidence of the action of structure on the organization, providing, therefore, empirical evidence for the notion of institutionalization as a recurrent process (Machado-da-Silva et al., 2005).

Finally, the study has found evidence to support the idea of organizational imprinting. Modes of response to pressures used by each company in the early days persisted throughout their existences. Other historical longitudinal studies into long-lived Brazilian firms are under way in order to verify the external validity of the findings reported here.

\section{ACKNOWLEDGMENTS}




\section{REFERENCES}

Aeppel, T. (1997, November 22). Famous name Westinghouse fades away. The Gazette, Montreal.

Birr, K. (1957) Pioneering in industrial research: the story of the general electric research laboratory. Washington, DC: Public Affairs Press.

Chandler, A. D. (1977). The visible hand. Cambridge: The Belknap Press of Harvard University Press.

Daniells, L. M. (1957). Studies in enterprise: a selected bibliography of American and Canadian company histories and bibliographies of businessmen. Boston: Harvard University.

DiMaggio, P. J., \& Powell, W. (1983). The iron cage revisited: institutional isomorphism and collective rationality in organization fields. American Sociological Review, 48, 147-160.

Donaldson, Lex (2002). Damned by our own theories: contradictions between theories and management education. Academy of Management Learning and Education, 1(1), 96-106.

Eisenhardt, K. (1989). Building theories from case study research. Academy of Management Review 14(4), 532-550.

Geahigan, P. C. (1988). U. S. and Canadian businesses, 1955 to 1987: a bibliography. Metuchen: The Scarecrow Press Inc.

Ghemawat, P. (1999). Strategy and the business landscape: text and cases. Reading: Addison-Wesley.

Hawkins, L. A. (1950). Adventure into the unknown: the first fifty years of the General Electric research laboratory. New York: William Morrow \& Co.

Hill, M. R. (1993). Archival strategies and techniques. Newbury Park [etc.]: Sage Publications.

Leblebici, H., Salancik, G., Copay, A., \& King, T. (1991). Institutional change and the transformation of interorganizational fields: an organization history of the U.S. radio broadcasting industry. Administrative Science Quarterly, 36, 333-363.

Machado-da-Silva, C., Fonseca, V., \& Crubellate, J. (2005). Estrutura, agência e interpretação: elementos para uma abordagem recursiva do processo de institucionalização. Revista de Administração Contemporânea, 9(1 ${ }^{\text {a }}$ Edição Especial), 09-39.

Meyer, J., \& Rowan, B. (1977). Institutionalized organizations: formal structure as myth and ceremony. American Journal of Sociology, 83(2), 340-363.

Meyer, M., \& Zucker, L. (1989). Permanently failing organizations. Newbury Park, CA: Sage Publications.

Oliver, C. (1991). Strategic responses to institutional processes. Academy of Management Review, 16(1), 145-179.

Oliver, C. (1992). The antecedents of deinstitutionalization. Organization Studies, 13(4), 563-588.

Porter, M. E. (1980). Competitive strategy: techniques for analyzing industries and competitors. New York: The Free Press. 
Selznick, P. (1957). Leadership in administration: a sociological interpretation. Berkeley: University of California Press.

Selznick, P. (1996). Institutionalism ‘Old’ and 'New’. Administrative Science Quarterly, 41, 270-277.

Scott, W. R. (1987). The adolescence of institutional theory, Administrative Science Quarterly, 32(4), 493-511.

Scott, R. (2001). Institutions and organizations. Thousand Oaks: Sage.

Stinchcombe, A. L. (1965) Social structure and organizations. In J. G. March (Ed.), Handbook of organizations (pp. 142-193). Chicago: Rand McNally.

Stinchcombe, A. L. (1997). On the virtues of the old institutionalism. Annual Review of Sociology, 23, $1-18$.

Sultan, R. G. M. (1974). Pricing in the electrical oligopoly Vol 1 Competition or Collusion. Cambridge, Massachusetts: Harvard University Press.

Zucker, L. (1987). Institutional theories of organization. Annual Review of Sociology, 13, 443-464. 